\title{
The Axiological Emancipation of a (Non-)Principle: Autonomy, International Law and the EU Legal Order
}

\author{
VIOLETA MORENO-LAX*
}

\section{Introduction: A Bridge or a Wall?}

The relationship between international law and EU law has long beguiled scholars. The literature on their interplay is copious. ${ }^{1}$ And there is no scarcity of titles dealing with the notion of autonomy as applied to the relationship between the two. ${ }^{2}$ Ever since Van Gend \& Loos, ${ }^{3}$ the processes of reception, compliance and contestation between the EU and international legal orders have attracted attention, with

\footnotetext{
${ }^{*}$ I am grateful to Dr Mario Méndez and Dr Paul Gragl for their helpful comments on a previous draft.

${ }^{1}$ See, generally, E Cannizzaro, P Palchetti and RA Wessel (eds), International Law as Law of the European Union (Martinus Nijhoff, 2012); P Eeckhout, EU External Relations Law, 2nd edn (Oxford University Press, 2011); M Evans and P Koutrakos (eds), Beyond the Established Legal Orders (Hart, 2011); J Wouters, A Nollkaemper and E de Wet (eds), The Europeanisation of International Law (TMC Asser Press, 2008); M Cremona and B de Witte (eds), EU Foreign Relations Law (Hart, 2008); TC Hartley, 'International Law and the Law of the European Union - A Reassessment' (2001) 71 British Yearbook of International Law 1; M Koskenniemi (ed), International Law Aspects of the European Union (Martinus Nijhoff, 1998).

${ }^{2}$ See, eg, T Schilling, 'The Autonomy of the Community Legal Order: An Analysis of Possible Foundations' (1996) 37 Harvard International Law Journal 389; JHH Weiler and UR Haltern, 'The Autonomy of the Community Legal Order - Through the Looking Glass' (1996) 37 Harvard International Law Journal 411; L Barents, The Autonomy of Community Law (Kluwer, 2004); B de Witte, 'European Union Law: How Autonomous is its Legal Order?' (2010) 65 Zeitschrift für öffentliches Recht 141.

${ }^{3}$ Case 26/62 Van Gend en Loos [1963] ECR 1. For a recent re-evaluation, see B de Witte, 'The Continuous Significance of Van Gend en Loos' in M Maduro and L Azoulai (eds), The Past and Future of EU Law (Hart, 2010) 9. cf I Pernice, 'The Autonomy of the EU Legal Order - Fifty Years After Van Gend' in A Tizziano, J Kokott and S Prechal (eds), 50th Anniversary of the judgment in Van Gend en Loos (Office des publications de l'Union européenne, 2013) 55.
} 
efforts being made to explicate the links and fissures concerning them. ${ }^{4}$ Authors have acknowledged the limits of dichotomous accounts - relying on concepts such as 'monism' and 'dualism', from the international/domestic discourse - focusing instead on the asymmetric and constantly adjusting nature of the relationship. ${ }^{5}$

However, the starting point remains questioned. On one hand, international lawyers tend to assume the Völkerrechtsfreundlichkeit of the EU system, ${ }^{6}$ considering the nature of the Union as a Treaty-based organisation with derivative legal personality, ${ }^{7}$ limited conferred competences ${ }^{8}$ and a pre-determined institutional set-up. ${ }^{9}$ The fact that it remains subject to the ultimate will of the Member States - which retain an untouched core of sovereignty, including the powers to amend the Treaties and quit the organisation - is also of note. ${ }^{10}$ On that basis, they take EU law as particular (lex specialis) international law; as a sub-system embedded within the system (of leges generales). ${ }^{11}$ On the other hand, EU lawyers emphasise the distinctive, sui generis nature of the integration project and its supranational legal regime, focusing on its high degree of constitutional development, institutional maturity and the density of the existing acquis. ${ }^{12}$

Whatever the perspective, the Treaties are not explicit in this regard. ${ }^{13}$ They say little about the place and ranking of international norms within the EU

\footnotetext{
${ }^{4}$ C Timmermans, 'The EU and Public International Law' (1999) 4 European Foreign Affairs Review 181; Besson, 'How International is the European Legal Order?' (2008) 5 No Foundations 50; B de Witte, 'Direct Effect, Primacy, and the Nature of the Legal Order' in P Craig and G de Búrca (eds), The Evolution of EU Law, 2nd edn (Oxford University Press, 2011) 323; and K Lenaerts, 'Direct Applicability and Direct Effect of International Law in the EU Legal Order' in I Govaere et al (eds), The European Union in the World (Martinus Nijhoff, 2014).

${ }^{5}$ KS Ziegler, 'International Law and EU Law: Between Asymmetric Constitutionalisation and Fragmentation' in A Orakhelashvili (ed), Research Handbook on the Theory of International Law (Edward Elgar, 2011) 268; E Cannizzaro, 'The Neo-Monism of the European Legal Order' in Cannizzaro, Palchetti and Wessel (n 1) 35; and V Moreno-Lax and P Gragl, 'The Quest for a (Fully-fledged) Theoretical Framework: Co-Implication, Embeddedness and Interdependency between Public International Law and EU Law' (2016) 35 Yearbook of European Law 455.

${ }^{6}$ E Cannizzaro, P Palchetti and RA Wessel, 'Introduction: International Law as Law of the European Union' in Cannizzaro, Palchetti and Wessel (n 1) 1; J Klabbers, 'Völkerrechtsfreundlich? International Law and the Union Legal Order' in P Koutrakos (ed), European Foreign Policy (Edward Elgar, 2011) 95.

${ }^{7}$ Art 47, Treaty on European Union [2010] OJ C83/13 ('TEU').

${ }^{8}$ Art 5(2) TEU and Art 249, Treaty on the Functioning of the European Union [2010] OJ C83/47 ('TFEU').

${ }^{9}$ Arts $13-19$ TEU.

${ }^{10}$ Arts 48 and 50 TEU.

${ }^{11}$ See, eg, A Pellet, 'Les fondements juridiques internationaux du droit communautaire' (1994) 5 Collected Courses of the Academy of European Law 193, 245.

${ }^{12} \mathrm{~J}$ Bengoetxea, 'The EU as (More than) an International Organization' in J Klabbers and A Wallendahl (eds), Research Handbook on the Law of International Organizations (Edward Elgar, 2011) 449. See also A Peters, 'The Position of International Law within the European Community Legal Order' (1997) 40 German Yearbook of International Law 9 and B de Witte, 'EU Law: Is it International Law?' in C Barnard and S Peers (eds), European Union Law, 2nd edn (Oxford University Press, 2017) 177.

${ }^{13}$ Arts 3(5) and 21 TEU are elaborated upon below. Regarding customary international law, see P Gragl, 'The Silence of the Treaties: General International Law and the European Union' (2015) 57 German Yearbook of International Law 375.
} 
legal order and fail to determine their effects and functions in particular situations, whether as gap fillers, validity measures, or interpretative guidelines. In the absence of specific provisions, the systematisation of the relationship has fallen to the Court of Justice of the European Union (CJEU), which has articulated it ad hoc and in piecemeal fashion.

The case law is unsystematic, according power and significance depending on the type of instrument and the function it may perform in the specific circumstances. ${ }^{14}$ Whilst the Court has reiterated its commitment to international law, retaining that the EU 'must respect [it] in the exercise of its powers, ${ }^{15}$ and holding that provisions in agreements concluded by the organisation 'form an integral part of [the Union's] law, ${ }^{16}$ this recognition has led to varying strategies, ranging from unswerving compliance with international norms to blatant instrumentalisation. ${ }^{17}$ But the fact that international rules be binding and have a place within the EU system does not automatically imply that they be selfexecuting. Generally, the reasoning has been outcome-driven, oscillating between openness and closeness of the regime, ${ }^{18}$ following a consequentialist approach to advance the EU cause - and preserve the Court's prerogatives. ${ }^{19}$

With this in mind, the Court has distinguished several degrees of intensity in the effects of international law, differentiating several methods of incorporation, each of them subject to different conditions - depending on whether international law is perceived to promote or impede EU powers. Ziegler has discerned, at least, three distinct mechanisms: direct effect; indirect effect or conform interpretation; and 'substantive borrowing. ${ }^{20}$ However, the gate-keeping criteria have fluctuated

\footnotetext{
${ }^{14}$ RA Wessel, Close Encounters of the Third Kind: The Interface between the EU and International Law after the Treaty of Lisbon, Swedish Institute of European Policy Studies (December 2013) www. sieps.se/en/publikationer/close-encounters-of-the-third-kind-the-interface-between-the-eu-andinternational-law-after-the-treat; $c f$ A Rosas, 'The European Court of Justice and Public International Law' in Wouters, Nollkaemper and de Wet (n 1) 75.

${ }^{15}$ Case C-286/90 Poulsen [1992] ECR I-6019 para 9; Case C-405/92 Mondiet [1993] ECR I-6133 paras 13-15; Case C-162/96 Racke [1998] ECR I-3655 para 45; Case C-308/06 Intertanko [2008] ECR I-4057 para 51.

${ }^{16}$ Case 181/73 Haegeman [1974] ECR 449 para 5; Case C-61/94 Commission v Germany [1996] ECR I-3989 para 52; Case C-311/04 Dordrecht [2006] ECR I-609 para 25.

${ }^{17}$ B de Witte, 'International Law as a Tool for the European Union' (2009) 5 European Competition Law Review 265. See also A Nollkaemper, 'The Duality of Direct Effect in International Law' (2014) 25 European Journal of International Law 105.

${ }^{18}$ On this oscillation, see BI Bonafé, 'International Law in Domestic and Supranational Settings' in J Kammehofer and J D’Aspremont (eds), International Legal Positivism in the Post-modern World (Cambridge University Press, 2014) 378 ff.

${ }^{19}$ For an elaboration, see B de Witte, 'A Selfish Court? The Court of Justice and the Design of Institutional Dispute Settlement Beyond the European Union' in M Cremona and A Thies (eds), The European Court of Justice and External Relations Law (Hart Publishing, 2014) 46.

${ }^{20}$ See Ziegler (n 5) 298-309. See also, KS Ziegler, 'The Relationship between EU Law and International Law' in D Patterson and A Södersten (eds), A Companion to EU Law and International Law (Wiley \& Sons, 2016) 42, 45. For a classification of four main uses of customary international law specifically: 1) to set the limits of jurisdiction and powers of the EU and/or the Member States; 2) as aid to interpretation; 3 ) as gap-filler of lacunae in EU law; and 4) as validity standards, see J Wouters and D van Eeckhoutte, 'Enforcement of Customary International Law through European Community Law'
} 
over time - with the Court holding the key to the door - from an a priori predisposition to the absorption of international norms, to a hostile exclusionism to guarantee the 'autonomy' of EU law.

And 'autonomy', as the remainder of this chapter will show, is not a static notion. ${ }^{21}$ It is an elusive concept that has travelled an intricate journey through several meanings and implications. ${ }^{22}$ It was first used to describe the distinctiveness of EU law, as the consequence of integration, to subsequently become the normative cause (or raison dêtre) of the European project. Autonomy has transformed from being a key tool to denote 'the specific characteristics of the EU and EU law, ${ }^{23}$ to implying the (normative aspiration of) closeness and self-sufficiency of the regime in its entirety. It has gone from being a (privileged) means securing the (formal) emancipation of EU law from its international roots, to becoming a (rootless) end in itself, detached from any identifiable value base - whether in the Rule of Law or in fundamental rights - despite Article 2 of the Treaty on European Union (TEU).

It will be argued that in the post Opinion $2 / 13$ isolationist era, ${ }^{24}$ a point of axiological vacuum has been reached, in which 'autonomy' per se has become a (new, if not the ultimate) value of the EU legal order. The objectivisation of 'autonomy' (and its veneration) means not only that EU law has been (substantively) detached from international law (and its principles), but also that the system as a whole has been emptied of the values on which 'the Union is founded', ${ }^{25}$ posing grave problems of legitimacy and self-justification. ${ }^{26}$ This chapter will, therefore, contest the nature of autonomy as a principle and challenge its axiological emancipation as being contrary to the Rule of (EU) Law.

in JM Prinssen and A Schrauwen (eds), Direct Effect: Rethinking a Classic of EC Legal Doctrine (Europa Law Publishing, 2002) 183.

${ }^{21}$ Speaking of a 'pattern' in the defence and promotion of autonomy by the CJEU, see A Łazowski and RA Wessel, 'When Caveats turn into Locks: Opinion 2/13 on Accession of the European Union to the ECHR' (2015) 16 German Law Journal 179.

${ }^{22}$ For an alternative classification of the 'meanings' of autonomy within the EU legal framework, see KS Ziegler, 'Autonomy: From Myth to Reality - or Hubris on a Tightrope? EU Law, Human Rights and International Law' in S Douglas-Scott and N Hatzis (eds), Research Handbook on EU Human Rights Law (Edward Elgar, 2017) 267. of T Molnár, 'Revisiting the External Dimension of the Autonomy of EU Law: Is There Anything New Under the Sun?' (2016) 57 Hungarian Journal of Legal Studies 178, distinguishing different 'types' of autonomy: relative/full, derivative/original.

${ }^{23}$ Opinion 2/13 EU Accession to the ECHR [2014] ECLI:EU:C:2014:2454 para 174.

${ }^{24}$ ibid. For a critique, see P Gragl, 'The Reasonableness of Jealousy: Opinion 2/13 and EU Accession to the ECHR' (2015) European Yearbook of Human Rights 27.

${ }^{25}$ Art 2 TEU.

${ }^{26}$ For an overview of this problématique, see J Klabbers, 'The Changing Image of International Organisations' in JM Coicaud and V Heiskanen (eds), The Legitimacy of International Organisations (United Nations University Press, 2001) 221. See also B Simma and D Pulkowski, 'Of Planets and the Universe: Self-Contained Regimes in International Law' (2006) 17 European Journal of International Law 483. 


\section{Chronicle of Autonomy's Phases: From Distinctiveness to (Strategic) Isolation}

Since the Lisbon Treaty came into force in 2009, mixed agreements are said to be 'binding upon the institutions of the Union and on its Member States. ${ }^{27}$ And it is also an explicit objective of the Union to 'uphold and promote' its values in its relations with the wider world, thereby contributing not only to 'the strict observance', but also to 'the development of international law. ${ }^{28}$ The EU, therefore, according to the very wording of Article 3(5) TEU, should emerge not only as a passive recipient, but also as an active shaper and guarantor of international norms. ${ }^{29}$ The relationship between the two regimes has, however, been put under constant strain, both pre- and post-Lisbon, mediated by the fluidity of 'autonomy'. The next sub-sections will show how, progressive tightness in the case law of the CJEU has, paradoxically, developed in the wake of the more international law-friendly language introduced by the Lisbon Treaty, tracking the evolution of 'autonomy' and the different roles it has played through the ages of European integration, from a quasi-empirical descriptor to a full normative notion, hailed as a sort of meta-principle of EU law in its latest incarnation.

\section{A. The Early Days of the 'New Legal Order': Autonomy as Descriptor?}

At the time of the Union's inception, as the European Coal and Steel Community in 1952 and the European Economic Community in 1957 respectively, the inextricable bond between the EU and international law went uncontested. Because this new legal construct had been established by sovereign States (as 'masters of the Treaties') via international agreements, there was no doubt that the Communities were creatures of international law, embedded in the general regime. ${ }^{30}$ Yet, the supervening times saw crucial developments, which raised questions regarding the EU's legal nature. The CJEU pursued an ever-deepening integration by pronouncing EU law supreme, ${ }^{31}$ and having direct effect within the Member States' legal systems under certain conditions, ${ }^{32}$ also elevating the Treaties as

\footnotetext{
${ }^{27}$ Art 216(2) TFEU. Note, however, that there is no corresponding provision regarding customary law.

${ }^{28}$ Art 3(5) TEU. See also Art 21(1) TEU.

${ }^{29}$ For a thorough account, see D Kochenov and F Amtenbrink (eds), The European Union's Shaping of the International Legal Order (Cambridge University Press, 2013).

${ }^{30}$ JHH Weiler, 'The Transformation of Europe' (1991) 100 Yale Law Journal 2403, 2413.

${ }^{31}$ Case 6/64 Costa v ENEL [1964] ECR 585, 594.

${ }^{32}$ Van Gend en Loos (n 3) 13.
} 
'the basic constitutional charter' of the Union. ${ }^{33}$ Consequently, the EU became an entity, which no longer was a 'pure' international organisation, but an increasingly 'constitutionalised' legal order. ${ }^{34}$

Whilst the CJEU pursued an integrating approach towards Member State law, it concurrently sought to differentiate EU law from its external basis in public international law. Although the Court still considered the then-Community a 'new legal order of international law' in Van Gend en Loos, ${ }^{35}$ it soon dropped the 'international law' qualifier, determining instead that, ' $[b] y$ contrast with ordinary international treaties, the EEC Treaty has created its own legal system....36 Autonomy in this context - which was not referred to in that way until the $1990 s^{37}$ - served to denote the distinctiveness of EU law, as an empirical as well as legal reality, describing how the EU, as a separate, special and 'autonomous' regime, pursued 'its own particular objectives. ${ }^{38}$ The stance at that point appeared to reflect the 'certain autonomy' predicated by the International Court of Justice of (all) international organisations, as independent subjects of international law. ${ }^{39}$

Normative consequences also follow from such characterisation - arguably, as would also occur with other instruments of international law. ${ }^{40}$ The CJEU indeed subsequently held that (other) international agreements cannot affect the autonomy of Union law, ${ }^{41}$ that 'the validity of any [Union] measure ... must be considered to be the expression ... of a constitutional guarantee stemming from the [EU] Treaty as an autonomous legal system, ${ }^{42}$ and that treaties concluded by the Union must not alter the functional nature and competences of its organs, including those of the Court of Justice. ${ }^{43}$ Autonomy thus emerged as an

\footnotetext{
${ }^{33}$ Case 294/83 Les Verts [1986] ECR 1339 para 23.

${ }^{34}$ JHH Weiler, The Constitution of Europe (Cambridge University Press, 1999) 12. See also T Lock, 'Why the EU is Not a State' (2009) 5 European Competition Law Review 345, 407-20; and ML Jones, 'The Legal Nature of the European Community' (1984) 17 Cornell International Law Journal 1. cf K Nicolaïdis, 'We, the Peoples of Europe...' (2004) 83 Foreign Affairs 97; and JA Caporaso, 'The European Union and Forms of State: Westfalian, Regulatory, or Post-modern?' (1996) 34 Journal of Common Markets Studies 29.

${ }^{35}$ Van Gend en Loos (n 3) 12 (emphasis added). For a theorisation, see K Culver and M Giudice, 'Not a System but an Order' in J Dickson and P Eleftheriadis (eds), Philosophical Foundations of EU Law (Oxford University Press, 2012) 54.

${ }^{36}$ Costa $v$ ENEL (n 31) 593 (emphasis added).

${ }^{37}$ Mapping this evolution, see S Szurek, 'Du particularisme à l'autonomie? Esquisses des rapports du droit international et du droit communautaire' (2007) 5 Annuaire du droit européen 57.

${ }^{38}$ Opinion 1/91 European Economic Area [1991] ECR I-6079 para 30.

${ }^{39}$ Legality of the Use by A State of Nuclear Weapons in Armed Conflict (Advisory Opinion) [1996] ICJ Rep 19.

${ }^{40}$ This is precisely why the pacta tertiis principle was codified in Art 34 of the Vienna Convention on the Law of Treaties [1969] 1155 UNTS 331 ('VCLT'); to ensure that '[a] treaty does not create either obligations or rights for a third State without its consent'.

${ }^{41}$ Case C-459/03 Commission v Ireland (Mox Plant) [2006] ECR I-4635 para 123. cf Art 344 TFEU.

${ }^{42}$ Joined Cases C-402/05 P and C-415/05 P Kadi and Al Barakaat International Foundation $v$ Council and Commission ('Kadi I') [2008] ECR I-6351 para 282.

${ }^{43}$ Opinion 1/09 European and Community Patents Court [2011] ECR I-1137 paras 76-89. See also Opinion 1/00 European Common Aviation Area [2002] ECR I-3498 para 12 ff; and Opinion 1/76 Inland Waterways ECLI:EU:C:1977:63.
} 
operational-constitutional factor, characterising the independent functioning of the EU as per the founding Treaties. ${ }^{44}$ Functionalism explained autonomy (at least in part), capturing the political, institutional and policy-making self-standingness of the EU as an international organisation in relation to both its Member States and other international actors. ${ }^{45}$

But the Court went a step further. By separating EU law from the rest of international law, it privileged the application of Union law within the legal systems of the Member States, in lieu of general international law, thereby consolidating its supremacy. The separation was tactical. The consequence for Member States was that they could no longer oppose or nullify the effectiveness of EU law through the invocation of domestic rules on the incorporation of 'classic' international law. The Court appropriated the instruments of its creation and 'liberated' the Union from such contingencies. It moved the source of its validation from international law to its own legal order and transformed the Treaties into the Grundgesetz of the EU's constitution. ${ }^{46}$ Autonomy in this framework played a primarily 'internal' role; the emancipation of EU law from international law was an instrument to claim the direct penetration of EU rules within the domestic systems of the Member States. There was no a priori animosity vis-à-vis international law implicit in the term. The description of EU law - and the normative re-configuration that ensued - as an autonomous form (of international law) served the purpose of a constitutional (and hierarchical) 'fusion' with Member State law. ${ }^{47}$

\section{B. The External Facet of Autonomy: Towards Kadi Dualism}

While the EU 'withdrew' from its international legal sources and was gradually 'autonomised', in the earlier days of integration it still displayed a 'monist' openness towards the international legal order. It allowed binding international norms to become ipso facto and without further transposition part of the Union legal regime, whether they took the form of international agreements, ${ }^{48}$ concluded by its own institutions, ${ }^{49}$ or of customary law - including principles from the law

\footnotetext{
${ }^{44}$ There was also external recognition of EU law as a 'special legal order', not least by the Strasbourg Court. See European Court of Human Rights ('ECtHR'), Moustaquim v Belgium, Application No 12313/86, 18 February 1991, para 49. For other examples, refer to Molnár (n 22) 186.

${ }^{45}$ On this point, see further R Collins and ND White, 'International Organisations and the Idea of Autonomy: Introduction and Overview' in R Collins and ND White (eds), International Organizations and the Idea of Autonomy (Routledge, 2011) 1. Generally on 'functionalism' and international organisations, see J Klabbers, An Introduction to International Organizations Law, 3rd edn (Cambridge University Press, 2015); and N Blokker, International Institutional Law, 6th edn (Brill, 2018).

${ }^{46} \mathrm{~N}$ Tsagourias, 'Conceptualizing the Autonomy of the European Union' in Collins and White (n 45) $339,340$.

${ }^{47}$ Case 106/77 Simmenthal [1978] ECR 629.

${ }^{48}$ Haegeman (n 16) para 5; and Case 104/81 Kupferberg [1982] ECR 3641 para 11, see further below. Most recently, see also Case C-266/16 Western Sahara EU:C:2018:118 paras 45-46.

${ }^{49}$ RA Wessel and S Blockmans, 'Between Autonomy and Dependence: The EU Legal Order under the Influence of International Organizations - An Introduction' in RA Wessel and S Blockmans (eds), Between Autonomy and Dependence (Springer, 2013) 1.
} 
of treaties, ${ }^{50}$ nationality awards, ${ }^{51}$ norms governing the obligation of States to allow access to their territory by their own nationals, ${ }^{52}$ the immunities applicable to heads of State, ${ }^{53}$ and the extent of jurisdictional powers, ${ }^{54}$ which were quasiautomatically absorbed. ${ }^{55}$

Even regarding a treaty the EU was not a party to, but to which all its Member States had acceded, such as the 1947 General Agreement on Tariffs and Trade (GATT), did the Court consider the Union to be bound by virtue of the doctrine of 'functional succession. ${ }^{56}$ The GATT had been adopted before the Communities came into existence. And, in International Fruit, ${ }^{57}$ the Court considered the Union subject to the agreement to the extent that it had assumed powers previously exercised by the Member States in the specific areas it regulated. Yet, it soon became clear that this did not amount to accepting that EU measures could be challenged, without more, on grounds of incompatibility with GATT norms. Similarly to the test for direct effect of EU law, the provisions at stake needed also to be capable of conferring rights, for which reason 'regard must be simultaneously paid to the spirit, the general scheme and the wording of the [treaty] and of the provisions concerned. ${ }^{58}$ On account of 'the great flexibility of its provisions', the GATT, however, was considered not to meet the mark, so it could not be invoked to challenge the lawfulness of Union law. ${ }^{59}$ The same applied to WTO provisions

\footnotetext{
${ }^{50}$ Racke (n 15) paras 25 ff; Case C-70/09 Hengartner [2010] ECR I-7233 para 36; Case C-386/08 Brita [2010] ECR I-2189 paras 44 ff; Case T-115/94 Opel Austria [1998] ECR II-2739 para 77.

${ }^{51}$ Case C-200/00 Chen [2004] ECR I-9925 para 37; Case C-135/08 Rottmann [2010] ECR I-1449 paras $39 \mathrm{ff}$; Poulsen (n 15) (nationality of ships).

${ }^{52}$ Case 42/74 Van Duyn [1974] ECR 1337 para 22.

${ }^{53}$ Case C- 364/10 Hungary v Slovakia ECLI:EU:C:2012:630 para 44.

${ }^{54}$ Joined Cases 3, 4 and 6-76 Kramer [1976] ECR 1279 paras 30-33; Joined Cases 89, 104, 114, 116, 117 and 125-129/85 Ahlström [1988] ECR 5193 para 18; Case C-366/10 Air Transport Association of America ('ATAA') ECLI:EU:C:2011:864 para $114 \mathrm{ff}$.

${ }^{55}$ Méndez speaks of a model of 'automatic incorporation'. See M Méndez, 'The Application of International Law by the Court of Justice of the European Union' in CA Bradley (ed), The Oxford Handbook of Comparative Foreign Relations Law (Oxford University Press, forthcoming). See further Wouters and van Eeckhoutte, 'Giving Effect to Customary International Law through European Community Law' in Prinssen and Schrauwen (n 20) 183; and T Konstadinides, 'When in Europe: Customary International Law and EU Competence in the Sphere of External Action' (2012) 13 German Law Journal 1177.

${ }^{56}$ This is in spite of the wording of what has become Art 351 TFEU, according to which: 'The rights and obligations arising from agreements concluded before 1 January 1958 ... between one or more Member States on the one hand, and one or more third countries on the other, shall not be affected by the provisions of the Treaties. To the extent that such agreements are not compatible with the Treaties, the Member State or States concerned shall take all appropriate steps to eliminate the incompatibilities established .....

${ }^{57}$ Joined Cases C-21-24/72 International Fruit Company [1972] ECR 1219. For elaboration and critique, see CD Ehlermann, 'Application of GATT Rules in the European Community' in M Hilf et al (eds), The European Community and GATT (Kluwer, 1986) 127; EU Petersmann, 'Application of GATT by the Court of Justice of the European Communities' (1983) 20 Common Market Law Review 397; and KJ Kuilwijk, The European Court of Justice and the GATT Dilemma (Nexed, 1996).

${ }^{58}$ Case 87/75 Bresciani [1976] ECR 129 para 16. For commentary, see S Riesenfeld, 'The Doctrine of Self-Executing Treaties and Community Law: A Pioneer Decision of the Court of Justice of the European Communities' (1973) 67 American Journal of International Law 504.

${ }^{59}$ International Fruit Company (n 57); and Case C-280/93 Germany v Council [1994] ECR I-4973 para 112. cf Fediol and Nakajima, allowing for very limited exceptions, whereby EU measures could be
} 
and decisions of its dispute settlement body, once the GATT was replaced by the World Trade Organisation (WTO) - even if the Union itself acceded to the treaty ${ }^{60}$ This position was hence taken as a break from the Court's previously predominantly 'monist' perspective. ${ }^{61}$

Subsequent cases confirmed the rupture. Intertanko restrained the criteria for direct effect of international agreements, refusing the review of legality of a Directive which practically incorporated an - albeit for the EU not formally binding - international convention (MARPOL) into EU law, on the basis that there had not been 'functional succession' entailing a full transfer of powers from the Member States in the areas at stake. ${ }^{62}$ It also denied the relevance of the UN Convention on the Law of the Sea (UNCLOS) - which the EU had ratified invoking the 'nature and structure' as well as the 'broad logic' of the treaty. Hitherto, EU courts had only precluded reliance on such grounds solely with regard to the GATT/WTO Agreement. ${ }^{63}$ Otherwise, where the relevant provision(s) were sufficiently clear, precise and unconditional - mirroring the criteria for direct effect of internal EU rules - international treaties concluded by the Union were deemed fit for purpose. ${ }^{64}$ Yet, UNCLOS was said not to confer rights on individuals, but rather on vessels via their flag State. And that prevented its use for validity review. The Court painted a picture of a pure inter-state agreement, disconnected from the rights that individuals (more or less directly) derived therefrom.

The ATAA case then made the annulment of EU legislation on the basis of international customary law nearly impossible - at least for non-privileged applicants.

challenged for incompatibility with GATT rules, where the EU measure concerned referred expressly to specific GATT provisions, or where the EU intended to implement a precise GATT obligation. See Case 70/87 Fediol EU:C:1989:254; and Case C-69/89 Nakajima EU:C:1991:186. Yet, there has not been any application of the Fediol and Nakajima doctrines, with the Petrotub ruling being the only exception. See Case C-76/00 P Petrotub EU:C:2003:4 cf Méndez (n 55), positing the decision is rather an example of 'a particular species of consistent interpretation' rather than a direct application of the Nakajima test.

${ }^{60}$ Case C-149/96 Portugal v Council [1999] ECR I-08395; and Case C-377/02 Van Parys [2005] ECR I-01465. For commentary, see S Griller, 'Judicial Enforceability of WTO Law in the European Union: Annotation to case C-149/96 Portugal v. Council' (2000) 3 Journal of International Economic Law 441; and J Jackson, 'International Law Status of WTO DS Reports: Obligation to Comply or Option to "Buy-Out”?' (2004) 98 American Journal of International Law 109.

${ }^{61}$ P Eeckhout, 'The Domestic Legal Status of the WTO Agreement: Interconnecting Legal Systems' (1997) 34 Common Market Law Review 11, 28-29. See also G de Búrca, 'The European Court of Justice and the International Legal Order after Kadi' (2010) 52 Harvard International Law Journal 1, 44 ff; and Méndez (n 55).

${ }^{62}$ Case C-308/06 Intertanko [2008] ECR I-4057 paras 49-50. See also International Convention for the Prevention of Pollution from Ships 1340 UNTS 61 and 1341 UNTS 3 ('MARPOL Convention'); and UN Convention on the Law of the Sea 1833 UNTS 3 ('UNCLOS'). For a critique, see Eeckhout (n 1) 398-400.

${ }^{63}$ On the evolution of the Court's approach, see M Méndez, The Legal Effects of EU Agreements (Oxford University Press, 2013) and C Hillion and P Koutrakos (eds), Mixed Agreements Revisited (Hart Publishing, 2010).

${ }^{64} \mathrm{cf}$ the more relaxed approach in Biotech and IATA, where the Court seems to do away with a rightsbased analysis to establish the invocability of international treaty provisions for validity review of EU law. Case C-377/98 Netherlands v Parliament and Council (Biotech) EU:C:2001:523; and Case C-344/04 IATA EU:C:2006:10. See also Case C-213/03 Pêcheurs de létang de Berre [2004] ECR I-07357. 
Thereafter, the conditions for individuals to fulfil require that 'first, those principles [of customary law] are capable of calling into question the competence of the European Union to adopt that act', beside that 'the act in question is liable to affect rights which the individual derives from European Union law ....65 The scope of review was, in addition, limited to establishing any 'manifest errors of assessment concerning the conditions for applying those principles, ${ }^{66}$ which further reduced any chances of success.

The Kadi saga, where the CJEU annulled a Regulation implementing a United Nations Security Council Resolution, because of its infringement of fundamental rights (Kadi I $)^{67}$ - a stance the Court confirmed, despite considerable, yet still insufficient, developments for the protection of due process guarantees at the UN level (Kadi II) ${ }^{68}$ - consolidated the trend. The Court adopted a stark 'dualist' stance; not only vis-à-vis customary or conventional international law of a particular kind, whether directly effective or not, but on a more general basis, proclaiming the Union an 'internal and autonomous legal order'. ${ }^{69}$ The move allowed Luxembourg to set aside international norms as irrelevant, to focus on the constitutionality assessment of the $E U$ measure at hand as per the standards of $E U$ law - others have praised the stance as one challenging the adequacy of the UN terrorist listing system; they consider that the upholds international human rights standards and contributes to their consolidation as universal values, ${ }^{70}$ but even in this light such upholds is achieved through the medium of $E U$ fundamental rights, ie by first 'Europeanising' international human rights.

These judgments show the CJEU's growing reluctance to ensuring compliance with international law as such, ${ }^{71}$ from building bridges to raising a 'dualist' wall with international law, ${ }^{72}$ in a bid to safeguard the Union's autonomy. ${ }^{73}$ Autonomy, however, takes on a new meaning in this phase, based on pragmatic and teleological arguments on the proper functioning of the EU and the achievement of Treaty goals. The Court provides it with a normative anchor in fundamental constitutional tenets: 'the principles of liberty, democracy and respect for human rights', which allow no departure therefrom under any circumstances. ${ }^{74}$ Autonomy is thus

\footnotetext{
${ }^{65}$ ATAA (n 54) para 107 (emphasis added).

${ }^{66}$ ATAA (n 54) para 110 (emphasis added). The ruling has also been criticised for further limiting the scope of the 'functional succession' doctrine. See eg J Wouters, J Odermatt, and T Ramopoulos, 'Worlds Apart? Comparing the Approaches of the European Court of Justice and the EU Legislature to International Law' in Cremona and Thies (n 19) 249.

${ }^{67}$ Kadi I (n 42).

${ }^{68}$ Joined Cases C-584/10 P, C-593/10 P and C-595/10 P Commission and Others $v$ Yassin Abdullah Kadi ('Kadi II') ECLI:EU:C:2013:518.

${ }^{69}$ Kadi I (n 42) para 317.

${ }^{70} \mathrm{cf}$ Eeckhout (n 1) 420-21.

${ }^{71}$ F Casolari, 'Giving Indirect Effect to International Law within the EU Legal Order: The Doctrine of Consistent Interpretation' in Cannizzaro, Palchetti and Wessel (n 1) 395.

${ }^{72}$ A Skordas, 'Völkerrechtsfreundlichkeit as Comity and the Disquiet of Neoformalism: A Response to Jan Klabbers' in Koutrakos (n 6) 126.

${ }^{73} \mathrm{G}$ de Búrca, 'The ECJ and the International Legal Order: A Re-Evaluation' in G de Búrca and JHH Weiler (eds), The Worlds of European Constitutionalism (Cambridge University Press, 2012) 108.

${ }^{74}$ Kadi I (n 42) para 303.
} 
presented as the consequence of the (substantive) hierarchy of norms within the EU legal order; ${ }^{75}$ it constitutes a (formal or procedural) 'means to an end' for the preservation of the (substantive) integrity of the most basic values of the system. In fact, Kadi II omits any reference to autonomy per se, deploying its 'dualist' logic exclusively from the perspective of the constitutional superiority of fundamental rights. ${ }^{76}$

Autonomy in the Kadi jurisprudence is preoccupied with the axiological 'foundation of the Union, ${ }^{77}$ from where the legitimacy of the order derives. It constitutes its vehicle and not (yet) an end in itself. Autonomy serves to introduce the notion of a hierarchy within EU primary law, justifying limits to the possibility of according priority to (conflicting) international law as a result, so that '.. obligations imposed by an international agreement cannot have the effect of prejudicing the constitutional principles of the [EU] Treaty, which include the principle that all [EU] acts must respect fundamental rights ..... ${ }^{78} \mathrm{Kadi}$ thus installs a sort of 'principled dualism' grounded in a special breed of 'super-primary' constitutional norms conveying the values of the organisation. ${ }^{79}$ As a result, while market freedoms (qua 'ordinary' primary law) may exceptionality be derogated from in accordance with today's Article 351 of the Treaty on the Functioning of the European Union (TFEU), 'any derogation from ... Article [2 TEU values]' is strictly forbidden. ${ }^{80}$ No (extraneous) source of (international) law - be it the UN Charter or imperative Security Council Resolutions - can force an interpretation of EU law in contravention of fundamental rights.

Yet, as the next section reveals, the journey of autonomy did not terminate here. There is a further shift, from form to substance, which emptied the notion of its normative justification.

\section{Opinion 2/13: The Autonomisation of Autonomy}

The Charter of Fundamental Rights - which after Lisbon produces legally binding effects $^{81}$ - can be taken to give expression to the founding values of the organisation mentioned in Kadi, translating in concrete terms the generic allusion to

\footnotetext{
${ }^{75}$ Rather than the cause - in diametrical opposition to Opinion 2/13 (see next section below).

${ }^{76} \mathrm{Kadi}$ II (n 68) para 66.

${ }^{77}$ Kadi I (n 42) para 303; see also paras 283 ff, 326 and 330.

${ }^{78}$ Kadi I (n 42) para 285.

${ }^{79}$ For a similar approach, shielding the more protective EU asylum rules from the influence of international humanitarian law (IHL) in situations regarding 'war refugees', see Case C-285/12 Diakité ECLI:EU:C:2014:39, drawing on Case C-465/07 Elgafaji [2009] ECR I-921. For analysis, see V Moreno-Lax, 'Systematising Systemic Integration: "War Refugees", Regime Relations and a Proposal for a Cumulative Approach to International Commitments' (2014) 12 Journal of International Criminal Justice 907; and V Moreno-Lax, 'Of Autonomy, Autarky, Purposiveness and Fragmentation: The Relationship between EU Asylum Law and International Humanitarian Law' in JF Durieux and D Cantor (eds), Refuge from Inhumanity (Brill, 2014) 295.

${ }^{80}$ Kadi I (n 42) para 303.

${ }^{81}$ Art 6(1) TEU. Charter of Fundamental Rights of the European Union [2010] OJ C83/02 ('CFR').
} 
'human rights and fundamental freedoms' enclosed in Article 2 TEU. It actually 'reaffirms' and is, therefore, based on the shared constitutional traditions of the Member States and their common international obligations. ${ }^{82}$ Its final goal is to strengthen the protection of human rights - 'Europeanised' qua fundamental rights - within the EU legal order. ${ }^{83}$

Post Lisbon, the Charter has become the primary reference point in cases involving fundamental rights disputes. ${ }^{84}$ When the rights and freedoms recognised in the Charter are at stake, the instrument provides the reference framework for analysis, so that recourse to external sources (such as the European Convention on Human Rights (ECHR $)^{85}$ ) is no longer the priority. ${ }^{86}$ However, the Charter is not self-sufficient. It is by design embedded in international human rights law, from which it borrows substance and legitimacy. This is clear from the multiple references to other instruments in the Charter Explanations, ${ }^{87}$ from the text of certain clauses, ${ }^{88}$ from the way in which the horizontal provisions have been articulated, ${ }^{89}$ and from its relationship to general principles. ${ }^{90}$

In Opinion 2/13, the Court, nonetheless, failed to acknowledge the organic interlocking of international human rights law and EU fundamental rights. Despite the structural permeability of EU law being constitutionally scheduled in Articles 6 TEU and 52 of the Charter of Fundamental Rights of the European Union (CFR), the CJEU omitted its recognition as one of the 'specific characteristics of the EU and EU law' ${ }^{91}$ - by which the Court itself is presumably bound..$^{92}$

\footnotetext{
${ }^{82}$ Recital 5, Preamble CFR.

${ }^{83}$ Recital 4, Preamble CFR (emphasis added).

${ }^{84}$ For a detailed review, see S Iglesias Sánchez, 'The Court and the Charter' (2012) 49 Common Market Law Review 1565.

${ }^{85}$ European Convention on Human Rights [1950] ETS 5 ('ECHR').

${ }^{86}$ Opinion of AG Cruz Villalón, Case C-70/10 Scarlet ECLI:EU:C:2011:255, delivered on 14 April 2011, para 30. For a critique of this approach, see G de Búrca, 'After the EU Charter of Fundamental Rights: The Court of Justice as a Human Rights Adjudicator?' (2013) 20 Maastricht Journal of European and Comparative Law 168.

${ }^{87}$ This includes the European Convention on Human Rights and Biomedicine [1997] ETS 164, as part of the normative grounding of Art 3 CFR, on the right to the integrity of the person; the International Covenant on Civil and Political Rights ('ICCPR') [1969] 999 UNTS 171, regarding Art 19 CFR, on the protection in the event of removal, expulsion or extradition, and Art 49 CFR, concerning the principles of legality and proportionality of criminal offences and penalties; and the International Convention on the Rights of the Child, [1989] 1577 UNTS 3, within the remit of Art 24 CFR, on the rights of the child. See Explanations Relating to the Charter of Fundamental Rights [2007] OJ C303/02, 18, 24, 25 and 30. Recall that, according to Art 52(7) CFR, the explanations provide 'guidance in the interpretation of this Charter' and thus 'shall be given due regard by the courts of the Union and of the Member States' (emphasis added).

${ }^{88} \mathrm{See}$, eg, Art 18 CFR explicitly referring to the Convention on the Status of Refugees ('Geneva Convention') [1951] 189 UNTS 150.

${ }^{89}$ According to Art 52(3) CFR, in particular, '[i]n so far as this Charter contains rights which correspond to rights guaranteed by the [European] Convention for the Protection of Human Rights and Fundamental Freedoms, the meaning and scope of those rights shall be the same as those laid down by the said Convention' (emphasis added).

${ }^{90}$ cf Case C-64/16 Associação Sindical dos Juízes Portugueses ECLI:EU:C:2018:117 para $29 \mathrm{ff}$.

${ }^{91}$ Opinion 2/13 (n 23) para 174.

${ }^{92}$ Art 19(1) TEU: 'The Court of Justice ... shall ensure that in the interpretation and application of the Treaties the law is observed'.
} 
Instead, the Court invoked and distorted the role of 'autonomy', tipping the balance towards its most exclusionary form. ${ }^{93}$ Although independence does not require autarky and isolation, this was perceived as the only way to discard the compatibility of the Draft Accession Agreement to the ECHR with EU law and maintain its exclusive jurisdiction to adjudicate upon it.

Accession was not to affect the Union's competences, nor was it to alter the constitutional architecture and especial features of EU law. Among these, the Court mentioned the 'structured network of principles, rules and mutually interdependent relations [engaging] the EU and its Member States ... in a "process of creating an ever closer union among the peoples of Europe". ${ }^{4}$ The integration project was considered 'the raison dêtre of the EU itself'; $; 5$ its ultimate aim. The legal structure supporting that process of integration was, in turn, said to be 'based on the fundamental premise that each Member State shares with all other Member States ... a set of common values on which the EU is founded' which 'implies and justifies the existence of mutual trust between the Member States that those values will be recognised and ... that the law of the EU that implements them will be respected'. 96

Fundamental rights do belong in that 'set of common values', but unlike the preeminent place accorded to them in Kadi, in Opinion 2/13 the Court sees them as subordinate to 'the structure and objectives of the EU'; they must be interpreted and applied within the EU in accordance with [its] constitutional framework. ${ }^{97}$ So, fundamental rights appear to descend from their super-primary law position to a plain ordinary-primary law rank. Rather than providing the EU regime with its underpinning axiological basis, providing substantive, value justification to the structure and objectives of the EU, there seems to be an evolution of fundamental rights becoming a sub-set of rules that remains constrained by the constitutional dynamics (and inertia) of the system. ${ }^{98}$

And the Court notes that within this set-up, the (newly found) 'principle' of mutual trust is of fundamental importance in EU law'. The Court ties in

\footnotetext{
${ }^{93}$ Ziegler speaks of 'aggressive formalistic constitutionalism' to characterise the stance. See KS Ziegler, 'Beyond Pluralism and Autonomy: Systematic Harmonization as a Paradigm for the Interaction of EU Law and International Law' (2016) 35 Yearbook of European Law 667, 668. cf P Eeckhout, 'Opinion 2/13 on EU Accession to the ECHR and Judicial Dialogue: Autonomy or Autarky?' (2015) 38 Fordham International Law Journal 955, 989 and 991-92, presenting it rather as a form of 'radical legal pluralism?.

${ }^{94}$ Opinion 2/13 (n 23) para 167.

${ }^{95}$ Opinion $2 / 13$ (n 23) para 172.

${ }^{96}$ Opinion $2 / 13$ (n 23) para 168.

${ }^{97}$ Opinion 2/13 (n 23) paras $169-70$ and 177.

${ }^{98}$ The pro-autonomy interpretation it seems to imply constitutes the EU equivalent of the much criticised in dubio mitius approach under international law, maximising State sovereignty over the effectiveness of contracted obligations. For a critique, see Lauterpacht, 'Restrictive Interpretation and Effectiveness in the Interpretation of Treaties' (1949) 26 British Yearbook of International Law 48. See also A Orakhelashvili, The Interpretation of Acts and Rules in Public International Law (Oxford University Press, 2008) 414.
} 
fundamental rights to compliance with that principle ${ }^{99}$ - instead of the other way round - stating that it 'requires' Member States 'save in exceptional circumstances, to consider all the other Member States to be complying ... with the fundamental rights recognised by EU law' - regardless of whether this is the case in practice or not. Indeed, the Court insists that, 'when implementing EU law, the Member States may ... be required to presume that fundamental rights have been observed by the other Member States, so that ... they may not check whether that other Member State has actually, in a specific case, observed the fundamental rights guaranteed by the $\mathrm{EU}^{\prime} 100$ - the compatibility of this reading with the principle of effective judicial protection gone unheeded.

This frontally contradicts findings by the Strasbourg Court in MSS and Tarakhel, ${ }^{101}$ where the Strasbourg Court found that an effective remedy requires scrutiny of compliance with human rights protection by the receiving State before a person can be transferred or deported there, regardless of whether that State is a Party to the ECHR or, even, a Member State of the EU. The stance also disputes the key principle of effective judicial protection of individuals' rights under EU law, 'referred to in the second subparagraph of Article 19(1) TEU [and] stemming from the constitutional traditions common to the Member States ... enshrined in Articles 6 and 13 [ECHR], and which is now reaffirmed by Article 47 of the Charter. ${ }^{102}$

The Luxembourg judges do acknowledge the conflict of this interpretation with ECHR standards. But they consider those (apparently higher) ECHR standards to be problematic, stating that

in so far as the ECHR would ... require a Member State to check that another Member

State has observed fundamental rights, even though EU law imposes an obligation of mutual trust between those Member States, accession is liable to upset the underlying balance of the EU and undermine the autonomy of EU law. ${ }^{103}$

\footnotetext{
${ }^{99}$ This was seen to a lesser extent in Joined Cases C-411/10 and C-493/10 NS \& ME ECLI:EU:C:2011:865; and in Case C-399/11 Melloni ECLI:EU:C:2013:107, where the Court balances both. For an appraisal, see Spreeuw, 'Do As I Say, Not As I Do: The Application of Mutual Recognition and Mutual Trust' (2012) 8 Cambridge Yearbook of European Legal Studies 505.

${ }^{100}$ Opinion 2/13 (n 23) paras 191-92 (emphasis added). $c f$ Joined Cases C-404/15 and C-659/15 PPU Aranyosi and Căldăraru ECLI:EU:C:2016:198 paras 90-98, tempering the approach in the context of the European Arrest Warrant and requiring that there be an assessment in the specific case, stating, nonetheless, that 'a finding that there is a real risk of inhuman or degrading treatment by virtue of general conditions of detention in the issuing Member State cannot lead, in itself, to the refusal to execute a European arrest warrant' (para 91). In such situation, 'the execution of that warrant must be postponed but it cannot be abandoned' (para 98).

${ }^{101}$ ECtHR, Tarakhel $v$ Switzerland, Application No 29217/12, 4 November 2014, paras 92-93. See also ECtHR, MSS v Belgium and Greece, Application No 30696/09, 21 January 2011.

${ }^{102}$ Associação Sindical dos Juízes Portugueses (n 90) para 35 (emphasis added). See also C-279/09 DEB ECLI:EU:C:2010:811 paras 29-33 (post-Lisbon); and C-432/05 Unibet ECLI:EU:C:2007:163 para 37 (pre-Lisbon).

${ }^{103}$ Opinion 2/13 (n 23) para 194 (emphasis added).
} 
Yet, the issue is whether EU law may objectively impose an obligation of mutual trust that discounts fundamental rights, making them ineffective (and even un-invocable) in the particular case.

Autonomy here seems to be re-conceptualised by the Court as unhindered self-rule, when considering that

the Member States have, by reason of their membership of the EU, accepted that relations between them as regards the matters covered by the transfer of powers ... to the $\mathrm{EU}$ are governed by EU law to the exclusion, if EU law so requires, of any other law. ${ }^{104}$

The 'autonomy' of the EU legal order is, hence, asserted both 'in relation to the laws of the Member States and in relation to international law', including the ECHR. ${ }^{105}$ But can EU law disconnect Member States inter se relations from international law en bloc, ${ }^{106}$ in such a categorical and unqualified a way - without even reserving international rules a subsidiary role to play as mere fallback regime? ${ }^{107}$

In this particular instance, isolation requires the revisiting of the relationship between the Charter and the ECHR first. Not only is the Charter taken as the primary source of human rights within the EU legal order, but the ECHR appears relegated to the position of 'any other international agreement.' ${ }^{108}$ The Court acknowledges that 'fundamental rights, as guaranteed by the ECHR, constitute general principles of the EU's law', but its 'particular significance', recognised in past jurisprudence, ${ }^{109}$ is no longer mentioned in this context. Nor is the fact that the Charter and the Treaties, albeit not formally, effectively incorporate the substance of the Convention into EU law - via Article 6 TEU and Article 52(3) CFR. ${ }^{110}$ On the contrary, the Court underlines that 'as the EU has not acceded to the ECHR, the latter does not constitute a legal instrument which has been formally incorporated into the legal order of the EU.'111 The Court distances itself further from the ECHR, by suggesting that it would only be after accession that the ECHR, "like any other international agreement concluded by the EU', would 'form an integral part of EU law', citing the ATAA case to support the claim. ${ }^{112}$ Curiously, the CJEU omits any reference to Article 52(3) of the Charter to articulate the relationship between it and the ECHR. It appeals instead to Article 53, but re-drafting its text,

\footnotetext{
${ }^{104}$ Opinion 2/13 (n 23) paras 193 and 212 (emphasis added).

105 Opinion 2/13 (n 23) para 170.

${ }^{106} \mathrm{cf}$ Eeckhout (n 93) 977, suggesting that disconnection clauses may be acceptable in certain policy domains, but it being inappropriate as a wholesale approach to the entirety of EU law.

${ }^{107} \mathrm{cf}$ International Court of Justice (ICJ), Jurisdictional immunities of the State (Germany $v$ Italy: Greece Intervening), Application by Germany of 23 December 2008, para 6: 'Outside the specific framework [of the EU Treaties] ... the [Member States] continue to live with one another under the regime of general international law'.

${ }^{108}$ Opinion 2/13 (n 23) para 180.

${ }^{109}$ Joined Cases 46/87 and 227/88 Hoechst [1989] ECR 2852 para 13.

${ }^{110}$ Eeckhout (n 93), 960 and 964. See also (n 89).

${ }^{111}$ Opinion 2/13 (n 23) para 179 (emphasis added).

${ }^{112}$ Opinion 2/13 (n 23) para 180 (emphasis added).
} 
mentioning that 'nothing therein is to be interpreted as restricting or adversely affecting fundamental rights as recognised, in their respective fields of application, by EU law and international law' and, then, inserting a mention to the effect of 'including the ECHR'.113

Relying on that provision, the Court seems to over-write the lex specialis in Article 52(3), which literally requires that, in case of matching rights, the ECHR provide the 'leading standard', as a minimum floor of protection, with the Charter potentially 'providing more extensive protection'. The Court reverses the relationship between Charter/ECHR in the name of the autonomy of EU law. When assessing the effect of Article 53 ECHR, allowing Contracting Parties to maintain or introduce a higher level of human rights protection within their domestic system than the one provided for in ECHR provisions, the Luxembourg Court posits that that power, as regards Contracting Parties that are also Member States of the EU, should be limited ... to that which is necessary to ensure that the level of protection provided for by the Charter', so that the 'primacy, unity and effectiveness of EU law are not compromised'. Sidelining Article 52(3) CFR, the coordination between the two instruments is purported to affect the reading of 'the rights recognised by the Charter that correspond to those guaranteed by the ECHR.'114

What the Court ultimately achieves is the reversal of the means-ends relationship between fundamental rights and the primacy, unity and effectiveness of EU law. Autonomy, encapsulating these 'specific characteristics of the EU and EU law, ${ }^{\prime 15}$ is emptied from the normative foundation that fundamental rights, as per the Kadi paradigm, could/should provide it with. In turn, fundamental rights are prevented from going too far, if that is perceived to impinge upon the primacy, unity and effectiveness (or 'autonomy' for short) of EU law. Drawing on what has been called a 'formalistic', ${ }^{116}$ 'free-standing teleological interpretation, ${ }^{117}$ autonomy is ultimately 'autonomised' by the Court to defend a (selective) set of 'special characteristics' of EU law, without identifying any particular reason or its justification - while 'respect for human rights' is an explicit founding value of the Union, nowhere is 'mutual trust' mentioned in the Treaties, let alone as core grounding of integration. ${ }^{118}$ It becomes an abstract principle, flexible enough to

\footnotetext{
${ }^{113}$ Opinion 2/13 (n 23) para 187 (emphasis added).

${ }^{114}$ Opinion 2/13 (n 23) para 189. cf Melloni (n 99).

115 Opinion $2 / 13$ (n 23) para 174.

${ }^{116}$ Editorial, 'The EU's Accession to the ECHR - a "NO” from the ECJ!' (2015) 52 Common Market Law Review 1, 11.

${ }^{117}$ Ziegler (n 22).

${ }^{118}$ To the contrary, although the CJEU reiterates the crucial character of 'mutual trust' as the backbone principle of the Area of Freedom, Security and Justice, the truth is that, according to Art 67 TFEU, the establishment of the AFSJ 'shall' (ie must) be undertaken 'with respect for fundamental rights'. Concurring: Eeckhout (n 93) 970; and S Peers, 'The EU's Accession to the ECHR: The Dream Becomes a Nightmare' (2015) 16 German Law Journal 213. In this regard, see also S Douglas-Scott, 'The EU's Area of Freedom, Security and Justice: A Lack of Fundamental Rights, Mutual Trust and Democracy?' (2008-2009) 11 Cambridge Yearbook of European Legal Studies 53.
} 
close off EU law at will, disallowing not only any external interference from international law into the EU legal order, but also denying subjection to the internal value-related constraints imposed by (EU) fundamental rights themselves.

Autonomy in Opinion 2/13 is 'objectivised', representing the 'sovereignitisation' of the Union and its legal order; ${ }^{119}$ becoming a (substantive) principle of its own, but without any axiological anchor. The consequences of this abstraction have become all too visible in subsequent case law.

\section{The Legacy of Non-accession to the ECHR: Venerating Autonomy as Such}

One may think that Opinion 2/13 was peculiar to the specific, thorny question submitted to the Court, which would entail a complete redesign of the institutional and constitutional framework of the EU legal order, by opening the system to external scrutiny by a non-EU body, thus (potentially) challenging the autonomy of the regime and the ultimate authority of the CJEU within it - though the Member States did not appear to share such perception when inserting Article 6(2) TEU into the Lisbon Treaty. It was certainly plausible to expect that there would have been no reflection in subsequent case law of the re-configuration of the place and effect of fundamental rights within the system of sources of EU law. This, however, has not been the case. There has been a wave of decisions that consolidate the exclusionary trend.

After Opinion 2/13, a (hollow) suprematised 'autonomy' of EU law has become an end in and of itself, to be cherished and pursued for its own sake. It is no longer the procedural rule allowing EU law to perform its functions and achieve its aims; nor is it a mere empirical descriptor of the system, part of the legal tapestry of integration. Autonomy thereafter is directly based on a reciprocal belief in the fiction of compliance with common standards across Member State jurisdictions, regardless of actual observance of fundamental rights on the ground. The inadequacy of replacing real compliance with erga omnes obligations (creating individual rights), with an inter-State presumption designed to accelerate expulsions and deportations (regardless of those same rights) has been neglected by the Court. Instead, autonomy has been mobilised to prevent appeals to reality beyond that assumed by the EU acquis - as interpreted by the Court - with the principle of loyal cooperation forcing Member States into compliance. ${ }^{120}$

This version of mutual confidence, as defined in Opinion 2/13, is not only independent from effective realities, but also shapes and constrains the content and extent of fundamental rights, which can thenceforth only be interpreted and

\footnotetext{
${ }^{119}$ Assessing autonomy as a claim to sovereignty in disguise, see JWC van Rossem, 'The Autonomy of the EU: More is Less?' in Wessel and Blockmans (n 49) 13, 25-17.

${ }^{120}$ Art 4(3) TEU.
} 
applied 'in accordance with the constitutional framework [of the EU]' and on account of its sui generis 'structure and objectives.' ${ }^{121}$ The cart has been put before the horses. EU objectives are no longer subservient to, and achievable within the margins of, compliance with fundamental rights - as checks on the possible excesses of power. The reverse is now true. Fundamental rights have instead been put at the service of Treaty goals; taken down the apex of the hierarchy of EU sources and substituted with a canon of near-blind trust in Member State performance. Instead of providing a normative basis, they have become a means of integration like any other, a tool within the body of the acquis, subjected to the imperatives (and whims) of constitutionalisation. If taken to its logical exhaustion, the reasoning leads to the justification of a 'market bias' in the realisation of EU fundamental rights, mediated (and limited) by the notion of autonomy. ${ }^{122}$

Autonomy appears to have subsumed the 'new kind of legal order' of the EU in its entirety, ${ }^{123}$ like an untold mystical source that translates the 'intrinsic nature' of the Union - as per the interpretation of its exclusive oracle, the Court - making the whole of EU law sacrosanct. ${ }^{124}$ As symbolic shorthand for (a specific collection of) EU objectives and structures, it incarnates 'the process of integration that is the raison d'être of the EU itself,', ${ }^{125}$ and must as such, therefore, be revered and 'preserved'126 - presumably even above and beyond the actual rights of the individuals for the benefit of whom integration is said to be enacted. ${ }^{127}$ The main preoccupation is to protect (this elevated version of) 'the underlying balance of the EU' and offset any threats that may 'undermine the autonomy of EU law.' ${ }^{128}$ Under this optic, fundamental rights are no longer the vehicle or inspiration of integration, but a potential obstacle to overcome when mutual trust and autonomy so demand.

Against this background, international human rights treaties - just as the ECHR in Opinion 2/13 - rather than recognised intrinsic value, as suppliers of general principles, Article 2 TEU foundations, or content-fillers of Charter entitlements, have been treated 'like any other international agreement.' ${ }^{129}$ The approach to the Convention on the Rights of Persons with Disabilities, ${ }^{130}$ which

\footnotetext{
${ }^{121}$ Opinion 2/13 (n 23) paras 177 and 170.

${ }^{122}$ Concurring: Ziegler (n 22) and D Kochenov, 'EU Law without the Rule of Law: Is the Veneration of Autonomy Worth It?' (2015) 34 Yearbook of European Law 74.

${ }^{123}$ Opinion 2/13 (n 23) paras 158 and 183.

${ }^{124}$ Opinion 2/13 (n 23) para 193. Concurring: Ziegler (n 22). This is not to deny that via Art 351 TFEU the Court has, at times, protected some Member State agreements vis-à-vis EU law. See eg J Klabbers, The European Union in International Law (Pedone, 2012) 60-67; cf P Koutrakos, EU International Relations Law, 2nd edn (Hart Publishing, 2015) 324-41. But the exception does not invalidate the rule.

${ }^{125}$ Opinion $2 / 13$ (n 23) para 172

${ }^{126}$ Opinion 2/13 (n 23) para 174.

${ }^{127}$ Van Gend en Loos (n 3) 12.

${ }^{128}$ Opinion $2 / 13$ (n 23) para 194

${ }^{129}$ Opinion $2 / 13$ (n 23) para 180.

${ }^{130}$ Convention on the Rights of Persons with Disabilities ('CRPD’) [2006] 2515 UNTS 3.
} 
the Union has ratified, and to the Convention on the Status of Refugees, ${ }^{131}$ directly incorporated in the body of the Treaties, offer particularly telling examples of this approach. ${ }^{132}$

The line of cases regarding the former, including HK Danmark ${ }^{133}$ and Glatzel, ${ }^{134}$ culminated on 18 March 2014 in Z, a Grand Chamber judgment treating the Convention as any other international agreement concluded by the European Union' (on whatever subject). ${ }^{135}$ The reasoning was later repeated in FOA, delivered on the same date as Opinion 2/13. ${ }^{136}$

In $Z$, the Court concluded that, since ratification by the EU, the Disability Convention must be considered to have become 'an integral part of the European Union legal order' and, therefore, 'capable of being relied on for the purposes of interpreting Directive 2000/78 [on equal treatment in employment]', especially for the purposes of defining the concept of 'disability' contained therein - which is not defined in EU law. ${ }^{137}$ The interpretative function of the Convention is thus accepted. But, when it comes to establishing whether the Convention can be relied upon to challenge the validity of the Directive, rather than 'Europeanising' the international disability rights it enshrines as part of the EU fundamental rights acquis (through the medium of Charter provisions, the general principles doctrine, or via direct application), the Court assimilates the instrument to the general category of international agreements and, rather than embracing the 'direct absorption' or embeddedness approach seen in past case law in relation to other international human rights norms, it relies on the Intertanko and ATAA criteria to establish whether it may produce direct effect.

Surprisingly, the conclusion reached by the Court is that the provisions of the Convention - in spite of the instrument explicitly seeking to 'promote, protect and ensure the full and equal enjoyment of all human rights and fundamental freedoms by all persons with disabilities, and to promote respect for their inherent dignity,' ${ }^{138}$ that is, aiming at the creation of an individual right to equality,

\footnotetext{
${ }^{131}$ Geneva Convention (n 88).

${ }^{132}$ A similar approach has been followed in relation to the Aarhus Convention on Access to Information, Public Participation in Decision-Making and Access to Justice in Environmental Matters [1998] 2161 UNTS 447, and investment treaties to which the EU is party, reaffirming (either explicitly or de facto) the autonomy of EU law against individual rights clauses therein. See Joined Cases 401/12 and 403/12 P Vereniging Milieudefensie ECLI:EU:C:2015:4; Joined Cases C-404/12 P and C-405 P Natuur en Milieu ECLI:EU:C:2015:5 and Case C-284/16 Achmea ECLI:EU:C:2018:158. For critical accounts see, respectively, S Gáspár-Szilágyi, 'The Relationship between EU Law and International Agreements: Restricting the Application of the Fediol and Nakajima Exceptions in Vereniging Milieudefensie' (2015) 52 Common Market Law Review 1059 and A Dimopoulos, 'Achmea: The Principle of Autonomy and its Implications for Intra and Extra-EU BITs' (EJILTalk!, 27 March 2018) www.ejiltalk.org/author/ adimopoulos/.

${ }^{133}$ Joined Cases C-335/11 and C-337/11 HK Danmark ECLI:EU:C:2013:222.

${ }^{134}$ C-356/12 Glatzel ECLI:EU:C:2014:350.

${ }^{135}$ Case C-363/12 Z ECLI:EU:C:2014:159 para 72.

${ }^{136}$ Case C-354/13 FOA ECLI:EU:C:2014:2463.

${ }^{137} Z$ (n 135) paras 73, 75 and 76 (emphasis added).

${ }^{138}$ Art 1 CRPD.
} 
entailing the obligation to remove any obstacles thereto - 'are not, as regards their content ... unconditional and sufficiently precise within the meaning of [Intertanko and ATAA]' to produce direct effect. Therefore, 'the validity of Directive 2000/78 [on equal treatment in employment] cannot be assessed in the light of the Convention. ${ }^{139}$

There is no article-by-article assessment or any detailed analysis of the concrete content of the Convention to buttress this finding. The only support the Court adduces to sustain its claim is that, 'in so far as the obligations imposed by that Convention are addressed to Contracting Parties', in the sense that it is Contracting Parties that bear the responsibility of adopting 'all appropriate ... measures for the implementation of the rights recognised in that Convention' - as it happens with essentially every Treaty, since individuals have no treaty-making powers of their own under international law and no independent capacity to implement international commitments - the international agreement shall be considered 'programmatic. ${ }^{140}$ The non sequitur nature of this logic is ignored by the Court. ${ }^{141}$ It is not that an international instrument be concluded and addressed to States (and the Union, in this case) as Contracting Parties that renders it programmatic. And what 'programmatic' actually means remains equally obscure. The Court relies on the general implementation clause of the Convention, in Article 4(1)(a) thereof, to deny invocability. Should the specification that 'States Parties [are subject to] adopt all appropriate legislative, administrative and other measures for the implementation of the rights recognised in the ... Convention' have been absent from the text, the Court would have been at pains to sustain its reasoning. The specification does no more than translate the general pacta sunt servanda principle to the Convention's terrain, according to which 'every treaty in force [programmatic or not] is binding upon the parties to it [including the Union and all its institutions] and must be performed by them in good faith'142 - including through the means expressly enumerated in Article 4(1)(a). In a sense, all international commitments - including those considered to be self-executing and/or conferring individual (human) rights - require practical observance and a form of real implementation on the ground to be effective. So, if taken to its ultimate conclusion, reliance on this point would virtually amount to a wholesale denial of invocability of all international law due to its 'programmatic' nature. ${ }^{143}$ organisations, the ICJ has famously held that, as subjects of international law, they 'are bound by any obligations incumbent upon them under general rules of international law, under their constitutions, or under any international agreements to which they are parties'. See Interpretation of the Agreement of 25 March 1951 between the WHO and Egypt (Advisory Opinion) [1980] ICJ Rep 73, 89-90.

${ }^{143}$ The absurdity of this position is illustrated by the Aarhus Convention litigation (n 132), wherein the CJEU rejects that Art 9(3), enshrining an access to justice provision within the Convention,
} 
The same dismissive approach towards international human rights law treaties has been adopted vis-à-vis the 1951 Refugee Convention in the inadmissibility decision of the Qurbani case, prolonging the shift of Opinion 2/13. ${ }^{144}$

Up to Qurbani, the 1951 Refugee Convention had been considered an example of the 'integration/embeddedness approach' to human rights. ${ }^{145}$ The instrument is mentioned in a Treaty provision, Article 78 TFEU, requiring the Union to adopt a common asylum policy 'ensuring compliance with the principle of non-refoulement' and in full 'accordance with the [1951] Geneva Convention'. The Convention has thus been described as a 'direct standard of decision,, ${ }^{146}$ compliance with which is required as a matter of EU law. ${ }^{147}$ This has meant that, in interpreting the common asylum acquis and in establishing its legality, the CJEU has taken the Refugee Convention as a main reference point and as a direct source of EU fundamental rights, mandating the Union and the Member States, when acting within the scope of EU law, to make sure 'the right to asylum [is] guaranteed with due respect for the rules of the Geneva Convention. ${ }^{\text {'48 }}$ The Convention acts as a minimum floor of protection in refugee matters - akin to the function assumed by the ECHR within EU law at large under Article 52(3) CFR. The instrument has indeed been acknowledged to constitute 'the cornerstone of the international legal regime for the protection of refugees', to which all preambles of all legislative acts adopted by the Union in the field of asylum law explicitly refer. ${ }^{149}$ What is more, legislation forming the Common European Asylum System

be sufficiently clear and unconditional to produce direct effect and substantiate the review of EU action. Further on the collision course the Court has placed the EU in relation to its international obligations, as interpreted by the Aarhus Convention Compliance Committee, see Méndez (n 55).

${ }^{144}$ Case C-481/13 Qurbani ECLI:EU:C:2014:2101.

${ }^{145}$ P Eeckhout, 'Human Rights and the Autonomy of EU Law: Pluralism or Integration?' (2013) 66 Current Legal Problems 169 (see further below).

${ }^{146} \mathrm{H}$ Battjes, European Asylum Law and International Law (Martinus Nijhoff, 2006) 101.

${ }^{147}$ For a full theorisation, see V Moreno-Lax, Accessing Asylum in Europe (Oxford University Press, 2017) Ch 7.

${ }^{148}$ Art 18 CFR. In this connection, the CJEU has established, in Abdulla, that '[u]nder Article 13 of the [Qualification] Directive, the Member State is required to grant refugee status to the applicant if he qualifies ...' (emphasis added). See Joined Cases C-175, 176, 178 and 179/08 Abdulla [2010] ECR I-1493 para 62. The same applies, as per M'Bodj, with regard to Art 18 of the Qualification Directive (n 149), according to which 'Member States are to grant that status to a third country national eligible for subsidiary protection' (emphasis added). See Case C-542/13 M'Bodj ECLI:EU:C:2014:2452 para 29.

${ }^{149}$ See Common Recital 3 of Directive 2011/95/EU of the European Parliament and of the Council of 13 December 2011 on standards for the qualification of third-country nationals or stateless persons as beneficiaries of international protection, for a uniform status for refugees or for persons eligible for subsidiary protection, and for the content of the protection granted [2011] OJ L337/9 ('Qualification Directive'); Directive 2013/32/EU of the European Parliament and of the Council of 26 June 2013 on common procedures for granting and withdrawing international protection [2013] OJ L180/60 ('Asylum Procedures Directive'); Directive 2013/33/EU of the European Parliament and of the Council of 26 June 2013 laying down standards for the reception of applicants for international protection [2013] OJ L180/96 ('Reception Conditions Directive'); and Regulation (EU) No 604/2013 of the European Parliament and of the Council of 26 June 2013 establishing the criteria and mechanisms for determining the Member State responsible for examining an application for international protection lodged in one of the Member States by a third-country national or a stateless person [2013] OJ L180/31 ('Dublin III Regulation'). 
(CEAS), especially the Qualification Directive, ${ }^{150}$ is deemed to have been 'adopted to guide the competent authorities ... in the application of that Convention', for which reason, the Directive 'must ... be interpreted in the light of its general scheme and purpose, while respecting the [Refugee] Convention ...'151 - a caveat absent from case law regarding other international treaties. So, up until Qurbani, the 1951 Convention was the ECHR equivalent (prior to Opinion 2/3) within the EU asylum system.

But just like Opinion 2/13 upsets the standing of the ECHR within the EU legal order, so does Qurbani in relation to the asylum acquis. The decision revisits the entire set-up and turns it upside down, assimilating the Refugee Convention to the 'normal' range of 'international agreements', which, if 'concluded' by the EU, would 'form an integral part of its legal order.' ${ }^{152}$ Because this is not the case - and due to the inadequate way in which the questions from the referring court had been worded, omitting any clear connection between Article 31 of the Convention, on the non-penalisation of refugees for their illegal entry into a country of asylum, and the EU rules on the admissibility of applications and border procedures - the Court declares to lack jurisdiction to interpret the Convention as such. The power of the CJEU 'extends only to rules which are part of EU law', the Court rightly asserts. ${ }^{153}$

This is in spite of past jurisprudence and other key factors acknowledged by the Court itself - including many of the above: that several pieces of EU legislation have been adopted in the field to which the Convention applies, ${ }^{154}$ that Article 78 TFEU provides that the common policy on asylum must be in accordance with the Convention, ${ }^{155}$ and that Article 18 of the Charter makes clear that the right to asylum is to be guaranteed with due respect for the Convention. ${ }^{156}$ The wider links to the Schengen acquis, establishing the rules applicable to admission in the Schengen area (as well as the relevant asylum-based exceptions), ${ }^{157}$ the Dublin implications of such non liquet conclusion, ${ }^{158}$ and the possible influence of, and on, the Returns Directive, ${ }^{159}$ are all disregarded.

\footnotetext{
${ }^{150}$ Qualification Directive (n 149). For analysis, see S Peers, V Moreno-Lax, M Garlick, and E Guild, EU Immigration and Asylum Law, 2nd edn (Brill, 2015) Vol 3, 65.

${ }^{151}$ See, eg, Abdulla (n 148) paras 51-53; Case C-31/09 Bolbol [2010] ECR I-5539 paras 36-38 and Joined Cases C-57 and 101/09 B and D [2010] ECR I- 979 paras 76-78 (emphasis added).

${ }^{152}$ Qurbani (n 144) para 22.

${ }^{153}$ Qurbani (n 144) para 21.

${ }^{154}$ Qurbani (n 144) para 24.

${ }^{155}$ Qurbani (n 144) para 25.

${ }^{156}$ Qurbani (n 144) para 25.

${ }^{157}$ Referring especially to Arts 3(b), 4, and 14(1), Union Code on the rules governing the movement of persons across borders (Schengen Borders Code) [2016] OJ L77/1. For a thorough account, see Moreno-Lax (n 147) Part II.

${ }^{158}$ Dublin III Regulation (n 149).

${ }^{159}$ Directive 2008/115/EC of the European Parliament and of the Council of 16 December 2008 on common standards and procedures in Member States for returning illegally staying third-country nationals [2008] OJ L348/98 ('Returns Directive').
} 
The Court adopts a very formalistic approach to disclaim jurisdiction. It is bizarre how it discounts the importance of Article 14(6) of the Qualification Directive, which expressly refers to Article 31 of the Geneva Convention - as the Court itself notes. ${ }^{160}$ The need to ensure the effectiveness and uniformity in the interpretation and application of EU asylum law are not enough to convince the judges, ${ }^{161}$ notwithstanding the diametrically opposed position they adopted in analogous judgments. As the Court acknowledges, in Bolbol and El Kott, ${ }^{162}$ on Palestinian refugees, Luxembourg 'did indeed accept that it had jurisdiction to interpret the provisions of the Geneva Convention to which EU law made a renvoi. ${ }^{163}$

Accepting that matters of formulation may rightly lead to a request for a preliminary ruling to be rejected, what is most worrisome is not the rejection per se, but the reasoning the CJEU (unnecessarily) deploys to substantiate its dismissal as if preparing the ground for Opinion $2 / 13$ and its aftermath - undermining the rank and significance of the Refugee Convention within the CEAS.

Qurbani could have been an unfortunate one-off case. Yet, its effects continue to be felt today. On the same day as Opinion 2/13, the Grand Chamber adopted two controversial decisions in defiance of international standards, isolating the CEAS, and lowering the level of EU asylum protection with regard to two seriously ill subsidiary protection claimants. ${ }^{164}$ And in February 2015, in Shepherd, the Court unduly narrowed down the scope of the definition of 'persecution', relying on a purely self-referential (and purportedly contra legem) interpretation of Article 9 of the Qualification Directive, in disregard of global trends and UNHCR materials on refugee status of conscientious objectors opposing military service. ${ }^{165}$ The self-referential, close-circuit approach to the interpretation of CEAS instruments that the Court has continued to pursue thereafter, relying pre-eminently on (a very textual reading of) secondary law, bear witness to the long-lasting legacy of Opinion $2 / 13 .^{166}$

\section{Internal, External and Axiological Autonomy: Rule of Law-less Emancipation}

Before Lisbon and Opinion 2/13, 'substantive borrowing' was the technique of penetration of international human rights law into EU law preferred by the

\footnotetext{
${ }^{160}$ Qurbani (n 144) para 27.

${ }^{161}$ Qurbani (n 144) para 26.

${ }^{162}$ Case C-31/09 Bolbol ECLI:EU:C:2010:351 and Case C-364/11 El Kott ECLI:EU:C:2012:826.

${ }^{163}$ Qurbani (n 144) para 28.

${ }^{164} M^{\prime} B o d j$ (n 148) and Case C-562/13 Abdida ECLI:EU:C:2014:2453.

${ }^{165}$ Case C-472/13 Shepherd ECLI:EU:C:2015:117.

${ }^{166}$ See further, V Moreno-Lax, 'Paradise Lost - From Elgafaji to Qurbani: Towards the HyperAutonomy of the Common European Asylum System?' (in progress).
} 
Court. The method was also employed, for instance, as regards norms of general international law on matters not regulated by (and arguably laying beyond the scope of) EU law, eg rules on the delimitation of State jurisdiction. ${ }^{167}$ These were adopted and applied quasi-automatically - sometimes qua general principles of EU law ${ }^{168}$ - without the Court analysing whether direct or indirect effect was possible or appropriate. At that point, (international/constitutional) human rights were 'Europeanised' as 'fundamental rights' and internalised or 'embedded' in the rest of the EU legal framework. ${ }^{169}$

Up to the adoption of the Charter, the EU lacked its own catalogue of rights. Instead, the CJEU 'transformed' international (and Member State constitutional) standards into internal EU law, borrowing from instruments, which were not formally binding on the Union. It was in Internationale Handelsgesellschaft where it was first established that 'respect for fundamental rights [as such and without further caveats] forms an integral part of the general principles of [EU] law protected by the Court of Justice, not necessitating an official act of incorporation. ${ }^{170}$ And, as general principles, unlike treaty law or international custom, fundamental rights were raised to the (highest) category of primary law. This was subsequently codified in Article 6(3) TEU and elevated to the status of 'founding values' of the Union in Article 2 TEU.

'[I]nternational treaties for the protection of human rights on which the Member States have collaborated or of which they are signatories' were considered key sources of 'inspiration' from which general principles were drawn. In particular, they supplied 'guidelines which should be followed within the framework of [EU] law. ${ }^{171}$ Again, although not formally binding on the Union, the ECHR was recognised to bear 'particular significance' in this context. ${ }^{172}$ But there are other examples: the Universal Declaration of Human Rights, ${ }^{173}$ the International Covenant on Civil and Political Rights, ${ }^{174}$ as well as the International Covenant on Economic, Social and Cultural Rights, ${ }^{175}$ among other instruments, were also taken into account.

\footnotetext{
${ }^{167}$ Kramer (n 54) paras 30-33; Ahlström (n 54) para 18; ATAA (n 54) para $114 \mathrm{ff.}$

${ }^{168}$ See, for instance, Racke (n 15) para 49 (pacta sunt servanda). See also Joint Cases C-120/06 P and C-121/06 P FIAMM and Fedon [2008] ECR I-6513 para 92 and Joined Cases C-20/01 and C-28/01 Commission v Germany [2003] ECR I-3609 para 24.

${ }^{169}$ Eeckhout (n 145).

${ }^{170}$ Case 11/70 Internationale Handelsgesellschaft [1970] ECR 1125 para 4 (emphasis added).

${ }^{171}$ Case 4/73 Nold [1974] ECR 491 para 13.

${ }^{172}$ Hoechst (n 109) para 13; Case C-260/89 ERT [1991] ECR I-2925 para 41; Case C-299/95 Kremzow [1997] ECR I-2629 para 14; Case C-274/99 P Connolly [2001] ECR I-1611 para 37; Case C-94/00 Roquette Frères [2002] ECR I-9011 para 25.

${ }^{173}$ Case C-135/08 Rottmann [2010] ECR I-1449 para 53, referring to the Universal Declaration on Human Rights, UNGA Res 217A (III), UN Doc A/810, 71 (1948).

${ }^{174}$ Case C-244/06 Dynamic Medien [2008] ECR I-505 para 39 ff; Case C-540/03 Parliament v Council [2006] ECR I-5769 para 37, referring to the ICCPR (n 87).

${ }^{175}$ Case C-73/08 Bressol [2010] ECR I-2735 para $85 \mathrm{ff}$, referring to the International Covenant on Economic Social and Cultural Rights [1969] 993 UNTS 3.
} 
Fundamental rights qua general principles were set to fulfil a dual function, providing a means of interpretation and a standard of validity and review of EU rules. ${ }^{176}$ One could argue that these were (and are), prima facie, the same functions (potentially) performed by other international law sources. The difference, though, is that human rights are first internalised and operate from within, as a matter of EU law. Any incompatibility of an act of the Union with human/ fundamental rights becomes thus one of internal inconsistency with the own constitutional values of the organisation.

Nevertheless, since the entry into force of the Charter, the relationship with international human rights law instruments has progressively been rarefied. Notwithstanding the 'bridges' to the ECHR in Article 52(3) CFR and to other relevant treaties in Article $53 \mathrm{CFR},{ }^{177}$ the 'internal' catalogue of EU fundamental rights has displaced the 'external' listings enshrined in parallel international human rights covenants, with the Court fostering a solipsistic reading of Charter rights - especially after Opinion 2/13, as elaborated above. Yet, there is no good reason for such a stance. The substance of Charter rights, as already stated, originates in common human rights obligations of the Member States, stemming from the shared constitutional traditions and joint international commitments the Charter 'reaffirms', ${ }^{178}$ and which continue to penetrate the EU legal order as both general principles and founding values of the organisation, even after the CFR codification. ${ }^{179}$

This is why the Opinion 2/13 paradigm can only be understood to represent an unwarranted emancipation of the EU legal order not only from external referents of human rights protection, but also from its own internal fundamental rights core. The form of $a$-axiological autonomy it propounds has drained the Union system of the substantive stratum pertaining to the Rule of Law. ${ }^{180}$ Kochenov explains this well. ${ }^{181} \mathrm{He}$ enlists the jurisdictio-gubernaculum binomial to designate the two main components of the principle. While gubernaculum represents the legality of the acquis of rules made in accordance with pre-established legal procedures, jurisdictio denotes 'the law above the law' to which the rulers are

\footnotetext{
${ }^{176}$ Opinion 2/94 [1996] ECR I-1759 para 34.

${ }^{177}$ See, eg, K Lenaerts, 'Exploring the Limits of the EU Charter of Fundamental Rights' (2012) 8 European Competition Law Review 375, 394, conceiving of Art 53 CFR as a 'stand-still' clause, precluding regressive interpretations of Charter rights in light of developments occurring in international (and constitutional) law. cf Melloni (n 99).

${ }^{178}$ Recital 5, CFR Preamble.

${ }^{179}$ Art 6(3) TEU and Art 2 TEU. On this co-existence of the Charter with general principles, see, eg, Case C-144/04 Mangold [2005] ECR I-9981 (pre-Lisbon); Case C-555/07 Kücükdeveci [2010] ECR I-365 (post-Lisbon) and Associação Sindical dos Juízes Portugueses (n 90) (post-Opinion 2/13).

${ }^{180}$ Generally, on the rule of law function of human rights, see L Lixinski, 'Taming the Fragmentation Monster through Human Rights? International Constitutionalism, "Pluralism Lite" and the Common Territory of the Two European Legal Orders' in V Kosta, N Skoutaris, and VP Tzevelekos (eds), The EU Accession to the ECHR (Hart, 2014) 231. See also E Voyakis, 'International Law and the Objectivity of Value' (2009) 22 Leiden Journal of International Law 51.

${ }^{181}$ Kochenov (n 122).
} 
subject (and that 'made them king'182). It is the compendium of value-related standards from which legality derives its legitimacy - the 'spiritual heart', in Allott's words, of the legal system; inimical to the untrammelled exercise of power. ${ }^{183}$ The two elements taken together encapsulate the duality of the law at the centre of the Rule of Law ideal. ${ }^{184}$

The neglect of jurisdictio, through a notion of autonomy that embraces only the legality component, constitutes an impoverished vision of the Rule of Law. It confounds the Rule of Law with the mere lawfulness of rules, whatever their axiological justification - it takes over the ideal of Justice inscribed in the Rule of Law absorbing its normativity away. ${ }^{185}$ What is more, in Opinion $2 / 13$ the idea of jurisdictio reining in gubernaculum is simply not tolerated. ${ }^{186}$ In fact, the EU Rule of Law it profiles has been reduced to mean that gubernaculum (or 'autonomy') reigns supreme. Hailing legality over legitimacy in this way pre-empts any jurisdictio-based questioning from within, making any challenge of the acquis well-nigh impossible. Apparently, this (autopoietic version postulated by the Court of the $E U$ ) Rule of Law is precisely mobilised to deactivate contestation. ${ }^{187}$

Yet, authority - including that of the Court - should remain bound by jurisdictio outside its own control - in order to prevent miscarriages of justice. ${ }^{188}$ No system governed by the Rule of Law can free itself from human (or fundamental) rights as ultimate demarcation between the legitimate use and abuse of power. ${ }^{189}$ The opposite makes the autonomous system of the EU emerge as a formally coherent legal order, bound by nothing else than the day-to-day norms of its own creation, with no higher aspiration beyond being shielded from external influence. To achieve this aim, human rights are first abstractly exscinded from their fundamental rights counterparts and then externalised - made into exogenous rules outside the internal legal order and rejected as extraneous means of validation.

\footnotetext{
${ }^{182}$ M Krygier, 'Inside the Rule of Law' (2014) 3 Rivista di filosofia del diritto 77, 84.

${ }^{183}$ P Allott, 'The European Community is not the True European Community' (1991) 100 Yale Law Journal 2485, 2499.

${ }^{184} \mathrm{G}$ Palombella, 'The Rule of Law as an Institutional Ideal' in L Morlino and G Palombella (eds), Rule of Law and Democracy (Brill, 2010) 3. See also G Palombella, 'The Rule of Law at its Core' in G Palombella and N Walker (eds), Relocating the Rule of Law (Hart Publishing, 2009) 17 and G Palombella, 'Beyond Legality - before Democracy: Rule of Law Caveats in the EU Two-level System' in L Closa and D Kochenov (eds), Reinforcing Rule of Law Oversight in the European Union (Cambridge University Press, 2016) 36.

${ }^{185}$ L Fuller, The Morality of Law rev edn (Yale University Press, 1969). See also J Raz, The Authority of Law: Essays on Law and Morality (Clarendon Press, 1979) and RH Fallon, 'Rule of Law as a Concept in Constitutional Discourse' (1997) 97 Columbia Law Review 1.

${ }^{186}$ Kochenov (n 122) 94.

${ }^{187}$ Kochenov (n 122) 95.

${ }^{188}$ Art 2 TEU. See also S Douglas-Scott, 'Justice, Injustice and the Rule of Law in the EU' in D Kochenov, G de Búrca, and A Williams (eds), Europe Justice’s Deficit (Hart Publishing, 2015) 51.

${ }^{189} \mathrm{M}$ Adams, A Meuwese and EH Ballin (eds), Constitutionalism and the Rule of Law (Cambridge University Press, 2017). cf A Williams, The Ethos of Europe (Cambridge University Press, 2010).
} 
The idea of autonomy the CJEU embraces is a remarkably reductionist notion, exclusively focused on negative protections from external (and externalised) restraint. It views it as pure self-determinism and unmolested self-action, suggesting the Union legal order should be considered autonomous 'for its own sake. The Court fails to acknowledge the fallacy of complete independence especially in an 'ever closer Union' precisely based on 'the universal values of the inviolable and inalienable rights of the human person, freedom, democracy, equality and the rule of law.' ${ }^{190}$ A self-determined choice to cooperate with others or to comply with outside standards that become internalised within the system does not amount to non-autonomy.

Autonomy does not need to involve splendid isolation by treating selfdeterminism as an entirely internal self-referential process. It may actually involve a reduction of independence or a decision to become dependent in certain situations. Autonomy is relational - predicated vis-à-vis another system, rule or entity. Co-legislation and co-validation through shared ideals, if freely self-imposed, constitutes as much an expression of autonomous will as the embracement of the purest form of autarky.

Willkür - in the Kantian sense - provides an escape from zero-sum games and a perception of autonomy in absolutising 'either/or' terms, refocusing attention on issues of legitimacy and the expression of common values reflective of mutual public reason. Autonomy in this light is not limited to its negative dimension, as solely meaning 'free from' dependence and 'exclusive of' external influence. It rather connotes a volonté distincte; a form of self-determinism, ensuring the capacity for autonomous choice in a system of joint production of rules and values. The ensuing normative principles of Dignity, Justice and intrinsic human worth are thereby co-generated as 'autonomous' standards, imposing common (external/internalised) constraints that are universally valid and restrict the freedom of everyone within the system (both the rulers and the ruled). ${ }^{191}$ Those standards provide the jurisdictio, the moral justification, to the gubernaculum originating in institutional conduct - whether of the Court or somebody else.

\section{Conclusion: 'Like Ships in the Night'}

The construal of autonomy qua autarky as a matter of course, as Luxembourg does in Opinion 2/13 and its sequels, is not tenable. There is no a priori determinism of what autonomy entails. And this is exemplified by the very evolution of the term in the Court's own case law that the foregoing sections have analysed - first, (implicitly) taking autonomy as a functional consequence of the Union being

\footnotetext{
${ }^{190}$ Recitals 2 and 13, Preamble TEU (emphasis added).

${ }^{191}$ For further analysis and references, see GW Brown, 'The Idea of Autonomy' in Collins and White (n 45) 104.
} 
constituted as an (independent) actor of international law; then, as a mechanism of emancipation from the Member States and as a tool to claim primacy and direct effect within their legal systems; later still, as a vehicle of constitutionalisation vis-à-vis international law (to preserve fundamental rights); to finally become detached from the EU founding values (to protect the entire legal order, and particularly the CJEU's jurisdiction within it, from any possible interference).

Autonomy should simply be the 'door' to the external world - the line of communication between orders, rules and values. Whether the door is then kept open or closed is a different issue. There is no necessary implication for autonomy to mean isolation. Reading into autonomy a predetermined substantive choice of insularity is not warranted. The decision is not fixed by autonomy itself. The notion does not automatically demand that 'the [EU] legal order and the international legal order pass by each other like ships in the night.. ${ }^{192}$ Internationalism and constitutionalisation are not mutually exclusive by definition, especially when it comes to human/fundamental rights. ${ }^{193}$

The decision to open or close the system can well be based on gubernaculum alone. But then the system as a whole requires jurisdictio to keep the power behind such decision in check and for compliance with its ultimate source of validation. External/internalised constraints are an essential feature of governance by law. ${ }^{194}$

The conversion of EU law into an autonomous island risks becoming self-destructive. Therein the Rule of Law becomes contingent and human/ fundamental rights relative and alienable; left at the mercy of the naked authority of the Luxembourg Court. ${ }^{195}$ The CJEU judges should, therefore, revisit their approach - the principle of loyalty (or 'mutual trust') applies to them too, enjoining them to engage in 'sincere cooperation' to assist the Union and its legal order 'in carrying out tasks which flow from the Treaties. ${ }^{196}$ The Treaties' choice to embed (universal) rights into EU law binds the Court and must inform its (re-)interpretation. ${ }^{197}$ Autonomy qua axiological emancipation from the very values of a 'community based on the rule of law'198 is unsustainable. It amounts to denying 'the ultimate purpose of all law'. ${ }^{199}$

\footnotetext{
192 Opinion of AG Maduro in Joined cases C-402/05 P and C-415/05 P Kadi ECLI:EU:C:2008:11, delivered on 16 January 2008, para 22.

${ }^{193}$ Concurring: Ziegler (n 22).

${ }^{194}$ HE Allison, Kant's Theory of Freedom (Cambridge University Press, 1990) 103. See also G Postema, 'Law's Autonomy and Public Practical Reason' in RP George (ed), The Autonomy of Law (Oxford University Press, 1996) 79 and P Capps, 'Autonomy in Kant's Philosophy of International Law' in Collins and White (n 45) 48.

${ }^{195}$ Eeckhout (n 93) 992.

${ }^{196}$ Art 4(3) TEU. See also Art 13(2) TEU.

${ }^{197} c f$ On the especial rank of human rights in international law, see S Gardbaum, 'Human Rights as International Constitutional Rights' (2008) 19 European Journal of International Law 749; ID Seiderman, Hierarchy in International Law: The Human Rights Dimension (Intersentia, 2001) and MT Kamminga and M Scheinin (eds), The Impact of Human Rights Law on General International Law (Oxford University Press, 2009).

${ }^{198}$ Les Verts (n 33) para 23.

${ }^{199}$ H Lauterpacht, International Law: Collected Papers (Cambridge University Press, 1975) Vol 2, 47.
} 